\title{
Long-stem Prosthesis for Intertrochanteric and Femoral Neck Fractures in the Elderly: Retrospective Comparison of Short-term Clinical Outcomes
}

\author{
Yaşlılarda Intertrokanterik ve Femur Boyun Kırıklarında Uzun Stemli Protezler: Kısa \\ Dönem Klinik Sonuçlarının Retrospektif Karşılaştırılması \\ (D) Çağdaş Biçen, (D) Mehmet Akdemir*, (D) Mehmet Aykut Türken, (D) Kübra Çekok** \\ Izmir University of Economics, Medicalpark Hospital Clinic of Orthopedics and Traumatology, Izmir, Turkey \\ *Konya Akademi Hospital, Clinic of Orthopedics and Traumatology, Konya, Turkey \\ **Izmir University of Economics, Medicalpark Hospital, Clinic of Physical Medicine and Rehabilitation, Izmir, Turkey
}

\section{Abstract}

Objective: Hip fracture treatment in elderly patients remains challenging. This study aimed to evaluate short-term clinical results of long-stem cementless arthroplasty in elderly patients with femoral neck and intertrochanteric fractures.

Materials and Methods: We collected data of patients we treated with long-stem cementless arthroplasty between January 2011 and December 2019 due to hip fractures. This study included 48 patients ( $\geq 65$ years of age) with femoral neck and intertrochanteric fractures. The patients underwent either bipolar or total hip arthroplasty. A 2-year follow-up was conducted in all the patients. Outcomes were evaluated with the Harris hip score (HHS), Koval categories, complications and hip and mid-thigh pain. We compared clinical results of patients with femoral neck fractures and those with intertrochanteric fractures.

Results: The mean follow-up period was 57 (34-92) months. Sixteen patients had femoral neck fractures and 32 had intertrochanteric fractures. No difference in demographic characteristics and comorbidities was noted between groups. The mean preoperative Barthel index of activities of daily living score was 79. At the last follow-up, the mean HHS of the control group was 77 and the mean Koval categories score was 3. Revision surgeries were conducted in two patients due to dislocation. Infection was observed in one patient and was treated by debridement and anti-biotherapy. Implant loosening and periprosthetic fractures were not noted.

Conclusion: With fair outcomes, long-stem cementless arthroplasty is a potential treatment for hip fractures in elderly patients. A longer follow-up to evaluate the efficacy of these prostheses is warranted.

Keywords: Femoral neck fractures, intertrochanteric fractures, arthroplasty, cementless, long-stem

\section{Öz}

Amaç: Yaşlılarda kalça kırıklarının tedavisi hala güçlükler içermektedir. Çalışmamızda; femur boyun ya da intertrokanterik kırığı olan yaşlı hastalarda uzun stemli çimentosuz artroplastinin kısa dönem klinik sonuçlarını değerlendirmeyi amaçladık.

Gereç ve Yöntem: Ocak 2011'den Aralık 2019'a kadar kalça kırı̆ı nedeniyle uzun stemli çimentosuz artroplasti ile tedavi ettiğimiz hastaların verilerini topladık. Femur boyun ya da intertrokanterik kırığı olan 48 hasta ( $\geq 65$ yaş) çalışmaya dahil edildi. Hastalara bipolar veya total kalça artroplastisi uygulandı. Tüm hastalar en az 2 yıl takip edildi. Sonuçlar Harris kalça skoru (HHS), Koval kategorileri, komplikasyon, kalça ağrısı ve uyluk önü ağrısı açısından değerlendirildi. Femur boyun kırığı olan hastalarla ve intertrokanterik kırığı olan hastaların klinik sonuçlarını karşılaştırdık.

Bulgular: Ortalama takip süresi 57 (34-92) aydı. On altı hastada femur boyun kırı̆ıı, 32 hastada intertrokanterik kııık vardı. Demografik özellikler ve komorbiditeler açısından gruplar arasında fark yoktu. Preoperatif, Barthel günlük yaşam aktivite indeksi puanı ortalama 79 olarak hesaplandı. Son kontrollerde ortalama HHS 77 ve Koval kategorileri 3'tü. Çıkık sebebiyle 2 hastaya revizyon uygulandı. Sadece 1 hastada enfeksiyon vardı ve debridman ve antibiyoterapi ile tedavi edilebildi. Implant yetersizliği veya periprostetik kırık hiçbir hastada görülmedi.

Sonuç: İyi klinik sonuçlarla, uzun stemli çimentosuz artroplasti yaşlı hastalarda kalça kırıklarının tedavisi için bir seçenek olabilir. Bu protezlerin etkinliğini değerlendirmek için daha uzun takip süreleriyle yapılmış çalışmalar daha uygun olacaktır. Anahtar kelimeler: Femur boyun kırı̆ı, intertroknaterik kırık, artroplasti, çimentosuz, uzun stem

Address for Correspondence/Yazışma Adresi: Çağdaş Biçen Asst. Prof. Dr., İzmir University of Economics, Medicalpark Hospital, Clinic of Orthopedics and Traumatology, İzmir, Turkey

Phone: +90 5062735678 E-mail: cagdasbicen@hotmail.com ORCID ID: orcid.org/0000-0002-0711-9376

Received/Geliş Tarihi: 22.06.2020 Accepted/Kabul Tarihi: 23.09.2020

${ }^{\circ}$ Copyright 2021 by the Turkish Osteoporosis Society / Turkish Journal of Osteoporosis published by Galenos Publishing House 


\section{Introduction}

Hip fractures are significant causes of mortality and morbidity in elderly (1). Hip fractures incidence is increasing and 6.26 million hip fractures per year is estimated for 2050 (2,3). Elderly patients with hip fractures show up with comorbidities including hypertension, cardiac disease, and diabetes. Consequently, early mobilization is needed in order to lower complications (4). Treatment modalities differ with type of hip fracture. Arthroplasty is chosen mostly for treatment of displaced femoral neck fractures (5). But treatment of unstable intertrochanteric fractures still remains controversial (6). Although most of the studies advise proximal femoral nail anti-rotation for these cases, recent papers show satisfactory outcomes with bipolar hemiarthroplasty $(\mathrm{BHA})(7,8)$. Some authors prefer internal fixation due to advantage of lower post-operative complications. However; cut out of lag screw, loss of reduction and conversion to arthroplasty are still debating issues of internal fixation with intramedullary nails $(9,10)$.

Type of arthroplasty is chosen regarding mobilization, cognitive functions, and tolerability of anesthesia. Patients who can walk out-doors with or without one walking stick, without cognitive disfunctions and those can tolerate longer anesthesia can be treated with total hip arthroplasty (THA) (11). Most of elderly with hip fractures are treated controversially with BHA. There are cemented and cementless options for arthroplasty. Cemented arthroplasty has advantages as; good fixation, lower aseptic loosening rated and less reported thigh pain (11). But due to increased risk of interoperative cardiac and respiratory complications; sufficient stability with cementless arthroplasty was tried to be achieved (12). Different types of cementless prosthesis were used by orthopedic surgeons. Although there are lots of studies at the literature over cementless arthroplasty elderly patients with hip fracture few reports are found investigating long-stem cementless arthroplasty in treatment of elderly patients with hip fractures. Long-stem cementless prosthesis were used mostly for revision surgeries. Outstanding long-term outcomes were achieved espeically in cases with femoral defects. Long-stem cementless prosthesis was thought by some orthopedic surgeons as an option for primary surgeries in osteoporotic patients regarding additional stability. In treatments of unstable intertrochanteric fractures; cementless long-stem designs fit stabily beginning from just distal site of the defected region and bone ingrowth to stem provides additional stability. In our study we aimed to show short term clinical outcomes of elderly patients with hip fractures; who were treated with cementless long-stem prosthesis.

\section{Materials and Methods}

We collected the data of the patients $\geq 65$ years of age with hip fractures from January 2011 to December 2019. The study was designed retrospectively. All procedures were conducted in accordance with the ethical standards of the Helsinki Declaration of 1975 , as revised in 2000 . Due to retrospective design of the study, additional informed consent was not obtained from the patients. Patients who were treated with long-stem prosthesis (Echelon, Smith \& Nephew, USA) due to hip fracture and had a minimum 2-year follow up was included in the study. All the fractures were osteoporotic fractures. Prosthesis used was same in all patients as; $190 \mathrm{~mm}$, manufactured from cobalt chromium and porous coated (Figure 1, 2). The treatment was either bipolar or THA. Patients with pathological fractures, concomitant pelvic fractures, with fractures older than seven days, patients who were prefracture bedridden or patients who were lost during follow-up were excluded from the study. A

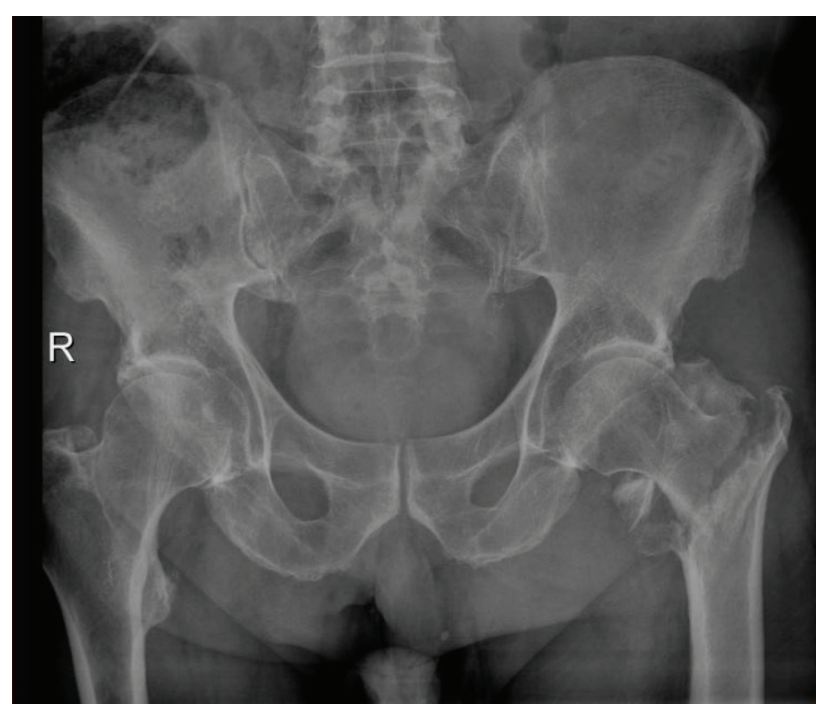

Figure 1. Preoperative $\mathrm{X}$-ray showing intertrochanteric fracture

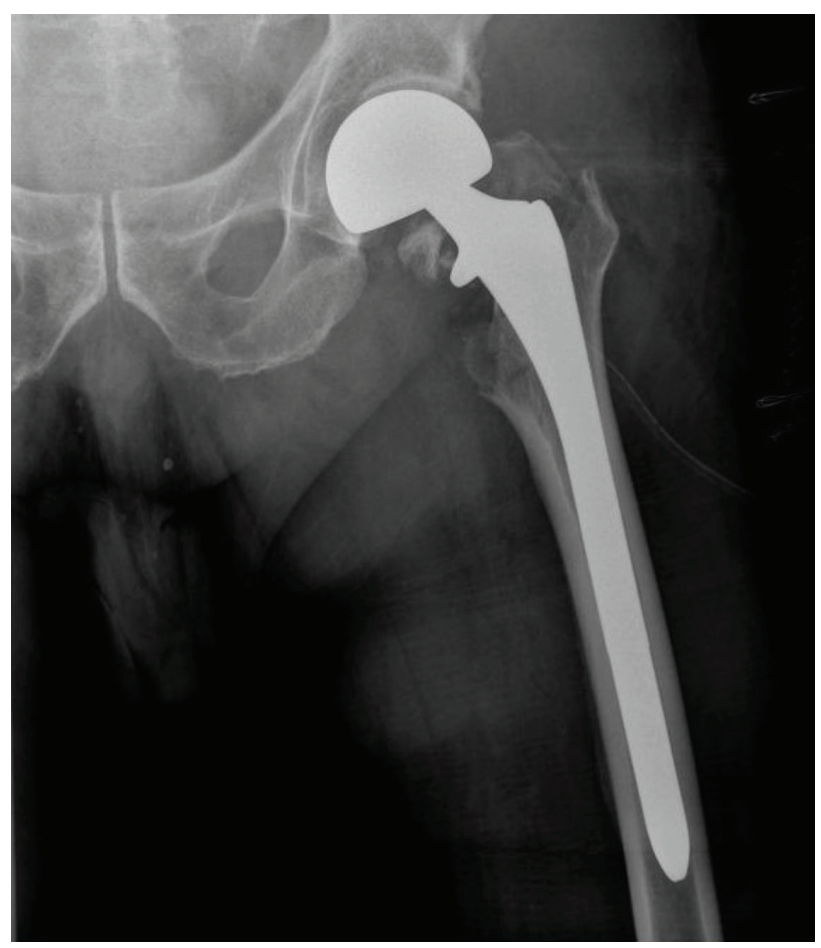

Figure 2. Post-operative X-ray showing treatment with long-stem cementless bipolar hemiarthroplasty 
total of 48 patients (38 female, 10 male) with a mean age of 81 (65-96) were evaluated. For assessments; age, gender, interval between fracture and operation, type of fracture, body mass index (BMI), American Society of Anesthesiologists (ASA) score, comorbidities, prefracture walking ability regarding score of Koval categories, prefracture Barthel index of activities of daily living ( $A D L)$ score, type of anesthesia, surgical time, number of blood transfusions, hospitalization day, type of prosthesis follow-up duration of the patients were recorded. Follow-up controls were performed at post-operative 6 weeks, 3, 6, 12 months and every year thereafter. On the follow-up controls for assessment of clinical outcomes, Koval categories, and Harris hip score (HHS) was used. The mobilisation ability of the patients were evaluated with score of Koval categories in every control (Figure 3) (Table 1) (13). The progression or regression of ambulatory capacity was compared with the prefracture and previous follow-up controls. Post-operative activities of the patients were evaluated regarding HHS (14). HHS was recorded for patients in every follow-up control and clinical improvement and returning to physical ability status of prefracture term was evaluated with HHS. Mid-thigh pain was also questioned in controls as a possible complaint of patients treated with cementless arthroplasty (15). For the pain located around hip visual analogue scale (VAS) was assessed in controls (16). Additionally early post-operative and late complications were recorded. Mean of score of Koval categories, HHS and VAS of the last control of the patients were assessed for comparison between both groups.

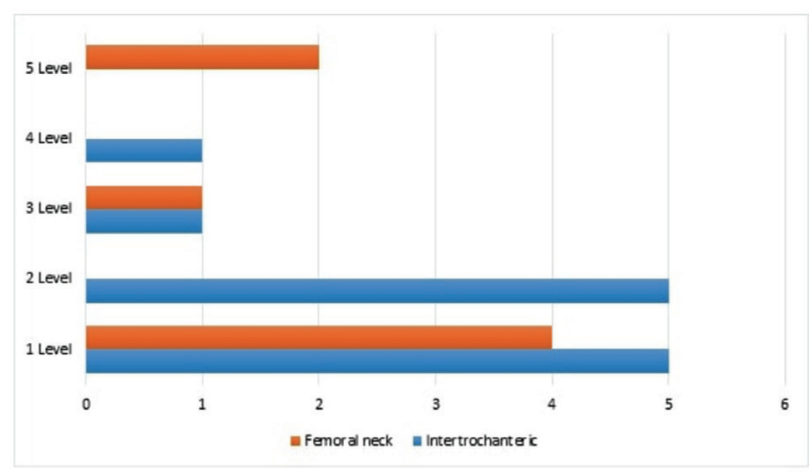

Figure 3. Regression of score Koval categories at the last control compared with preoperative levels

Table 1. Categories of walking ability by Koval

\begin{tabular}{|l|l|}
\hline Categories of walking ability by Koval & Scores \\
\hline Independent community ambulatory & 1 \\
\hline Community ambulatory with cane & 2 \\
\hline Community ambulatory with walker & 3 \\
\hline Independent household ambulatory & 4 \\
\hline Household ambulatory with cane & 5 \\
\hline Household ambulatory with walker & 6 \\
\hline Non-functional ambulator & 7 \\
\hline
\end{tabular}

\section{Surgical Technique}

Operations were performed by the same surgical team general or spinal anesthesia.

For BHA lateral approach was used in lateral decubitus position. Following capsulotomy, femoral head and fractured fragments were removed. Femoral canal was reamed and prepared for rasping. After rasping with help of stem trial, the stability, leg length and the size of them stem were controlled. Femoral stem was inserted to femoral canal. Then displaced trochanteric fragments were fixed with cerclage wires. Reduction was done after deciding bipolar neck length and size with trial reduction. The operation was completed closing wounds. For THA after removing femoral head, before femoral canal preparation acetabular component was implanted. In order to prepare acetabulum retractors were positioned. After verifying landmarks acetabulum was reamed. Acetabular component was implanted. Then femoral stem was implanted as describe above. Insert was set after trial reduction was performed. And the operation was completed with closing wounds. For antibiotic prophylaxis $1 \mathrm{gr}$ cefazolin was begun intravenously; within 30 minutes before the incision and continued with three doses next 24 hours. Low molecular weight heparin was used daily for 30 days for thromboembolism prophylaxis. Drains were removed 24 hours after surgery. Blood was performed with hemoglobin $<85 \mathrm{~g} / \mathrm{L}$ and regarding patients' complaints and symptoms. All the patients were encouraged with full weight bearing mobilization on the post-operative first day.

Measurements were done; hospitalization duration and time from fracture to operation as days, blood transfusion in terms of units and surgical time as skin-to-skin in minutes. Clinical outcomes were defined as HHS at the last control, changes in score of Koval categories comparing preoperative status with the last control in terms of average. Complications were recorded as early post-operative and late complications. Mid-thigh pain was also questioned and pain in the operated hip was calculated with VAS.

\section{Statistical Analysis}

Statistical analysis was performed using statistical package SPSS version 17 SPSS. Quantitative data were expressed with mean \pm standard and for categorical variables data were presented as percentage. Shapiro-Wilk test showed that quantitative data were not normally distributing and consequently nonparametric tests were used. Existence of statistically significant difference between quantitive data of two independent groups was analyzed by Mann-Whitney $U$ test and existence of statistically significant difference between categorical data was analyzed by chi-square test. When values in cells were 5 or above 5 Pearson test was used, when below 5 Fisher's Exact test was used. $P$ value was accepted as $p=0.05$ in $95 \%$ confidence interval. $\mathrm{P}<0.05$ was accepted as statistically significant. 


\section{Results}

Fourty eight patients were followed up minimum 2 years with mean 57 (24-92) months. Sixteen patients had femoral neck fractures and 32 had intertrochanteric fractures, in 21 patients fracture was in left hip and in 27 in right hip. All the fractures were presented as osteoporotic fractures. Mean BMI of the patients was 26 (18-39). Hypertension (26) was the most common comorbidity, followed by diabetes (13) and cardiac disorders (12). Six patients had diagnosis of dementia. Preoperative ADL score was an average of 79 and mean score of Koval categories was 2. Time from fracture to surgery was mean 2 days. Mean ASA score of the patients was 2 (Table 2). Thirty nine patients underwent BHA and 9 patients underwent THA. Seven patients were operated under general anesthesia and 41 patients under spinal anesthesia. Surgical times was average of 77 minutes. Mean hospitalization duration was 6 days and average of blood transfusion given was two units per patient. At the last follow-up control mean HHS was 77 and mean score of Koval categories, was seen to be regressed to 3. VAS was calculated as an average of 1 and mid-thigh pain was present in 6 (12.5\%) patients. At the early post-operative stage one patient with BHA suffered from urinary tract infection and one patient with THA needed debridement a month after operation due to wound infection. One patient with THA had dislocation three weeks after the operation. Closed reduction was performed. Cause having redislocation three weeks later, the patient was taken to revision surgery. As a late complication one of our patients had dislocation on 9th month for two times, revision surgery was done also to this patient after $2^{\text {nd }}$ dislocation, following closed reduction in the first dislocation. At the last follow-up control, three patients were nonfunctional ambulatory. The patients were divided in two groups. Patients with femoral neck fractures were defined as group 1 and patients with intertrochanteric fractures were defined as group 2. There was no statistically significant difference between two groups of regarding demographic and preoperative functional status. There was also no significant difference on hospitalization days, blood transfusions and postoperative complications. HHS and score Koval categories were also found similar in both groups (Table 3).

Table 2. Demographic characteristics and preoperative status of the patients

\begin{tabular}{|l|l|l|l|}
\hline & Femoral neck & Intertrochanteric & p \\
\hline Number of patients & 16 & 32 & - \\
\hline Mean age of operation (year) & $81(67-88)$ & $81(65-96)$ & $0.776^{*}$ \\
\hline Gender (female:male) & $15: 1$ & $23: 9$ & $0.132^{* *}$ \\
\hline ASA classification & 0 & 3 & \multirow{2}{*}{$0.492^{*}$} \\
\hline I & 0 & 15 & \\
\hline II & 8 & 13 & $0.371^{*}$ \\
\hline III & 8 & 78 & $0.709^{*}$ \\
\hline Preoperative ADL (mean) & 81 & 3 & $0.904^{*}$ \\
\hline Preoperative Score of Koval categories (mean) & 2 & 26 & \\
\hline Body mass index & 26 & & \\
\hline $\begin{array}{l}\text { ASA: American Society of Anesthesiologists, ADL: Activities of daily living } \\
\text { *Mann-Whitney U test, **Fisher's Exact test }\end{array}$ & & \\
\hline
\end{tabular}

Table 3. Intraoperative and post-operative variables of the groups

\begin{tabular}{|c|c|c|c|}
\hline & Femoral neck & Intertrochanteric & $\mathbf{p}$ \\
\hline \multicolumn{4}{|l|}{ Prosthesis (number) } \\
\hline Bipolar hemiarthroplasty & 15 & 24 & \multirow{2}{*}{$0.238^{*}$} \\
\hline Total arthroplasty & 1 & 8 & \\
\hline Mean unit of transfusion (number) & 2 & 2 & $0.138 * *$ \\
\hline Time from fracture to surgery (day) & 1 & 2 & $0.732 * *$ \\
\hline Mean duration of hospitalization (day) & 6 & 6 & $0.347^{* *}$ \\
\hline \multicolumn{4}{|l|}{ Complications (number) } \\
\hline Early & 0 & 2 & $0.546^{\star}$ \\
\hline Late & 2 & 2 & $0.592^{*}$ \\
\hline Score of Koval categories in last control (mean) & 3 & 3 & $0.911^{* *}$ \\
\hline Harris hip score in last control (mean) & 76 & 78 & $0.709 * *$ \\
\hline
\end{tabular}




\section{Discussion}

In treatment of hip fractures in elderly, in order to avoid mortality and morbidities; main purpose is thought as achieving prefracture mobilization status and functions as early as possible. For this reason, arthroplasty is advised by some authors regarding mobilization with early weight bearing and few implant failures $(17,18)$. Arthroplasty can be performed either cementless or cemented. Cemented stems have been chosen by some surgeons suggesting as being initially more stable when compared with cementless stems $(19,20)$. But intraoperative cardiopulmonary complications are still debating issues of cemented prosthesis. Though cementless prosthesis seem as good options to avoid these problems, increasing stability of these stems have become concerning. Recent studies show good outcomes with cementless stems without any complication related with stability $(4,21)$. Cementless prosthesis are available with short, standard, and long-stems. Although there are lots of studies at the literature over cementless stems, few studies are reported on long-stem cementless prosthesis in treatment of hip fractures in elderly $(4,22,23)$.

In our study, we observed that, in treatment of hip fractures in elderly, long-stem cementless prosthesis provided satisfactory clinical outcomes with low complication rates. The patients could restore their prefracture functions with early mobilization. We have not come upon to any perioperative cardiopulmonary complications. Only two of our patients needed revision surgery, both due to dislocation related with traumas. We observed implant related infection in one patient, which recovered after debridement and antibiotherapy without need of implant removal. Although there are studies suggesting that rate of periprosthetic fracture is increased with cementless arthroplasty, we have not seen any periprosthetic fracture $(24,25)$. We saw that pain was not present in most of our patients. In our mean 59 months follow-up none of our patients suffered from implant failure.

Although there are studies showing good outcomes with cemented stems in treatment of hip fractures, bone cement implantation syndrome is still a debating issue. The syndrome is presented just after cementing; with sudden hypotension, arrhythmia, hypoxia, pulmonary hypertension, cardiogenic shock and even with cardiac arrest (26). The mechanism is still not clear but, thermic, anaphylactic, and inflammatory processes have been accused (27). Cemented arthroplasty related intraoperative mortality rates were shown as $0.11-4.3 \%$ in studies over hip fractures, differing by type of fracture and type of arthroplasty $(27,28)$. The rates were $0.20 \%$ for intracapsular and $1.6 \%$ for intertrochanteric fractures. We choose cementless stems in order to avoid perioperative cardiopulmonary complications. We did not experience any such complications in our cases. And we think that our outcomes were compatible with studies reporting treatment of in hip fractures in elderly with cemented hemiarthroplasty $(29,30)$.
Choy et al. (21) presented 40 patients treated with cementless bipolar arthroplasty with diagnosis of intertrochanteric fracture. Mean age of the patients was 78.8. Mean follow-up period of the patients was 40.5 months. Most of the patients could be able to return to their daily activities. HHS at the last controls was calculated with an average of 80.6. They did not experience any intraoperative death or periprosthetic fracture. Only in 3 patients superficial infection developed and all could be treated without implant removal. They achieved good functional outcomes in their patients with cementless bipolar arthroplasty and none of the patients had implant loosening in follows.

In the study of Lee et al. (22), clinical outcomes of 96 patients treated with cementless BHA were reported. Significant number of patients had regression in mobilization status regarding score of Koval categories similar with our study. Only 3 patients had activity related mid-thigh pain and in small number of patients they observed cortical porosis but none of the patients needed revision surgery due to implant failure.

Chang et al. (1) published outcomes of patients consisting femoral neck and intertrochanteric fractures treated with cementless BHA. The patients were in similar age and preoperative clinical status with our study. They reported few surgical complications in both group with satisfactory clinical results. HHS was found mean 66.9 in intertrochanteric group and 68.1 in femoral neck group. As short term results they did not have any implant related complication.

Kim et al. (23) reported their midterm functional outcomes and survival rates of elderly patients with intertrochanteric fractures, whom they treated with long-stem BHA. They followed their patients for mean of 61.8. They did not experience any stem implant failure. Two of their patients had dislocation and 6 of the patients had periprosthetic fracture caused by falling. They also saw that score of Koval categories regress during elongated as the follow-up duration but clinical scores were fair at the last controls of the patients with mean 77 points of HHS. Except periprosthetic fractures findings of our study was comparable with this study similar demographic characteristics of patients. In our study there were also patients with femoral neck fractures and these patients' clinical outcomes were also outstanding like those of intertrochanteric fractures.

\section{Study Limitations}

Our study has several limitations. First, our study was designed retrospectively. Second, study consists of limited number of patients that were not so homogeneous. Another issue was lacking of control groups. Comparison with group of patients who had cemented arthroplasty would be more informative. Since we were not preferring cemented arthroplasty due to perioperative complications only, there were only few patients in this group and the number was not enough for comparison. The follow-up period was also not so long. This has always become a challenging issue for hip fractures in elderly patients because of high mortality rates and difficulties to go on with regular followup controls. Despite these limitations, we believe that our study 
shows that long-stem cementless arthroplasty is advisable for elderly patients with hip fractures.

\section{Conclusion}

We observed clinical outcomes of our patients for a mean of 57 months. HHS of the patients were fair and most of the patients were able to ambulate with or without any support. None of our patients suffered from loosening. With outstanding functional results, we believe that long-stems prosthesis can be chosen as a treatment option hip fractures in elderly. At the literature long-stem prosthesis was used for treatment of intertrochanteric fractures. We used these type of prosthesis also for femoral neck fractures. Long-stem prosthesis has an advantage of additional stability with diaphyseal press fit locking. We think that long-stem cementless prosthesis can be preferred in elderly patients with femoral neck fractures among those with poor bone quality.

\section{Ethics}

Ethics Committee Approval: Research was performed without any conflict of ethical issues.

Informed Consent: All procedures were conducted in accordance with the ethical standards of the Helsinki Declaration of 1975, as revised in 2000. Due to retrospective design of the study, additional informed consent was not obtained from the patients.

Peer-review: Externally and internally peer-reviewed.

\section{Authorship Contributions}

Surgical and Medical Practices: Ç.B., M.A., M.A.T., Concept: M.A.T., Design: Ç.B., Data Collection or Processing: K.Ç., Analysis or Interpretation: M.A., Literature Search: Ç.B.,

Writing: Ç.B.

Conflict of Interest: No conflict of interest was declared by the authors.

Financial Disclosure: The authors declared that this study received no financial support.

\section{References}

1. Chang JD, Kim IS, Lee SS, Yoo JH, Hwang JH. Unstable intertrochanteric versus displaced femoral neck fractures treated with cementless bipolar hemiarthroplasty in elderly patients; a comparison of 80 matched patients. Orthop Traumatol Surg Res 2016;102:695-9.

2. Alexiou KI, Roushias A, Varitimidis SE, Malizos KN. Quality of life and psychological consequences in elderly patients after a hip fracture: a review. Clin Interv Aging 2018;13:143-50.

3. Veldman HD, Heyligers IC, Grimm B, Boymans TA. Cemented versus cementless hemiarthroplasty for a displaced fracture of the femoral neck: a systematic review and meta-analysis of current generation hip stems. Bone Joint J 2017;99:421-31.

4. Lee YK, Won H, Roa KRU, Ha YC, Koo KH. Bipolar hemiarthroplasty using microarc oxidation-coated cementless stem in patients with unstable intertrochanteric fracture. J Orthop Surg (Hong Kong) 2019;27:2309499019847815.

5. Brox WT, Roberts KC, Taksali S, Wright DG, Wixted JJ, Tubb CC, et al. The American Academy of Orthopaedic Surgeons EvidenceBased Guideline on Management of Hip Fractures in the Elderly. J Bone Joint Surg Am 2015;97:1196-9.
6. Nie B, Wu D, Yang Z, Liu Q. Comparison of intramedullary fixation and arthroplasty for the treatment of intertrochanteric hip fractures in the elderly: A meta-analysis. Medicine (Baltimore) 2017;96:7446.

7. Zhou S, Liu J, Zhen P, Shen W, Chang $Y$, Zhang $H$, et al. Proximal femoral nail anti-rotation versus cementless bipolar hemiarthroplasty for unstable femoral intertrochanteric fracture in the elderly: a retrospective study. BMC Musculoskelet Disord 2019;20:500.

8. Kim SH, Meehan JP, Lee MA. Surgical treatment of trochanteric and cervical hip fractures in the United States: 2000-2009. J Arthroplasty 2013;28:1386-90.

9. Ma KL, Wang $X$, Luan FJ, Xu HT, Fang $Y$, Min J, et al. Proximal femoral nails antirotation, Gamma nails, and dynamic hip screws for fixation of intertrochanteric fractures of femur: A meta-analysis. Orthop Traumatol Surg Res 2014;100:859-66.

10. Bendo JA, Weiner LS, Strauss E, Yang E. Collapse of intertrochanteric hip fractures fixed with sliding screws. Orthop Rev 1994;(Suppl):30-7.

11. Robertson GA, Wood AM. Hip hemi-arthroplasty for neck of femur fracture: What is the current evidence? World J Orthop 2018;9:235-44.

12. Lee YK, Ha YC, Chang BK, Kim KC, Kim TY, Koo KH. Cementless bipolar hemiarthroplasty using a hydroxyapatite-coated long stem for osteoporotic unstable intertrochanteric fractures. J Arthroplasty 2011;26:626-32.

13. Koval KJ, Aharonoff GB, Rosenberg AD, Bernstein RL, Zuckerman JD. Functional outcome after hip fracture. Effect of general versus regional anesthesia. Clin Orthop Relat Res 1998;348:37-41.

14. Harris WH. Traumatic arthritis of the hip after dislocation and acetabular fractures: treatment by mold arthroplasty. An endresult study using a new method of result evaluation. J Bone Joint Surg Am 1969;51:737-55.

15. Andress HJ, Kahl S, Kranz C, Gierer P, Schürmann M, Lob G. Clinical and finite element analysis of a modular femoral prosthesis consisting of a head and stem component in the treatment of pertrochanteric fractures. J Orthop Trauma 2000;14:546-53.

16. Búcs $G$, Dandé Á, Patczai $B$, Sebestyén A, Almási $R$, Nöt LG, et al. Bipolar hemiarthroplasty for the treatment of femoral neck fractures with minimally invasive anterior approach in elderly. Injury 2021;52(Suppl 1):37-43.

17. Stappaerts KH, Deldycke J, Broos PL, Staes FF, Rommens PM, Claes P. Treatment of unstable peritrochanteric fractures in elderly patients with a compression hip screw or with the Vandeputte (VDP) endoprosthesis: a prospective randomized study. J Orthop Trauma 1995;9:292-7.

18. Bonnevialle P, Saragaglia D, Ehlinger M, Tonetti J, Maisse N, Adam $P$, et al. Trochanteric locking nail versus arthroplasty in unstable intertrochanteric fracture in patients aged over 75 years. Orthop Traumatol Surg Res 2011;97(6 Suppl):95-100.

19. Bottner F, Zawadsky M, Su EP, Bostrom M, Palm L, Ryd L, et al. Implant migration after early weightbearing in cementless hip replacement. Clin Orthop Relat Res 2005;436:132-7.

20. Rao RR, Sharkey PF, Hozack WJ, Eng K, Rothman RH. Immediate weightbearing after uncemented total hip arthroplasty. Clin Orthop Relat Res 1998;349:156-62.

21. Choy WS, Ahn JH, Ko JH, Kam BS, Lee DH. Cementless bipolar hemiarthroplasty for unstable intertrochanteric fractures in elderly patients. Clin Orthop Surg 2010;2:221-6.

22. Lee YK, Joung HY, Kim SH, Ha YC, Koo KH. Cementless bipolar hemiarthroplasty using a micro-arc oxidation coated stem in patients with displaced femoral neck fractures. J Arthroplasty 2014;29:2388-92.

23. Kim JT, Kim HH, Kim JH, Kwak YH, Chang EC, Ha YC. Mid-Term Survivals After Cementless Bipolar Hemiarthroplasty for Unstable Intertrochanteric Fractures in Elderly Patients. I Arthroplasty 2018;33:777-82.

24. Gjertsen JE, Lie SA, Vinje T, Engesæter LB, Hallan G, Matre K, et al. More re-operations after uncemented than cemented hemiarthroplasty used in the treatment of displaced fractures of the 
femoral neck: an observational study of 11,116 hemiarthroplasties from a national register. J Bone Joint Surg Br 2012;94:1113-9.

25. Streit MR, Merle C, Clarius M, Aldinger PR. Late peri-prosthetic femoral fracture as a major mode of failure in uncemented primary hip replacement. J Bone Joint Surg $\mathrm{Br}$ 2011;93:178-83.

26. Parvizi J, Holiday AD, Ereth MH, Lewallen DG. The Frank Stinchfield Award. Sudden death during primary hip arthroplasty. Clin Orthop Relat Res 1999;369:39-48.

27. Olsen F, Kotyra M, Houltz E, Ricksten SE. Bone cement implantation syndrome in cemented hemiarthroplasty for femoral neck fracture: incidence, risk factors, and effect on outcome. $\mathrm{Br} J$ Anaesth 2014;113:800-6.

28. Donaldson AJ, Thomson HE, Harper NJ, Kenny NW. Bone cement implantation syndrome. Br J Anaesth 2009;102:12-22.

29. Chandran P, Azzabi M, Burton DJ, Andrews M, Bradley JG. Mid term results of Furlong LOL uncemented hip hemiarthroplasty for fractures of the femoral neck. Acta Orthop Belg 2006;72:428-33.

30. Eiskjaer S, Gelineck J, Søballe K. Fractures of the femoral neck treated with cemented bipolar hemiarthroplasty. Orthopedics $1989 ; 12: 1545-50$ 